\title{
SELF-CONTROL TEACHING IN EARLY AGE
}

\author{
Sanja Čalović \\ Milena Krtolica \\ University of Montenegro \\ Faculty of Philosophy \\ Department for Educational Sciences \\ sanjac@ac.me \\ kmilena@ac.me
}

DOI:10.5901/mjss.2014.v5n22p368

\begin{abstract}
This paper is saying about importance of self-control in early age. Developed self-control is a pre-condition of developing willingness, capability of concentration and independence of a child. Child is capable of cooperation for which was stimulated by inner motives. Child is able to accept demand, to listen, but not only for "pure " obedience. Confirmation for that is asking for explanation, reasons, and different options of the solution of a problem. More attention, persistence enable successful realisation of started activities. Consequence of it, further, is development of independence, supported by a teacher. After theoretical analysis of key questions determining the sense and importance of self-control, there are given results of empirical analysis, more precisely results found on the base of long-term observation, according to previously prepared protocols of teachers, which is their work on development of self-control in early age. The given results reflect the state from one teaching unit and they represent qualitative indicators. In order to get more detailed review, there are also given results of focus group interview with teachers. Self-control of children depends on overall climate which, among other things, should offer: honest, not just declarative respect for children and their rights; timely recognition and meeting of children's rights; adequate model of teachers' behaviour able to question their acts. Development of self-control is especially influenced by well-planned and successful life regime, but which is flexible enough to adapt children's needs and capacities. In this paper, we were primarily focused on the role of a teacher in self-control development process. It seems that our practice has been "overtaken " by tradition control over a child. There is often imposed organisation of sleeping and eating schedule, which implicitly express a need for self-control. In order to get more objective findings on that, we have targeted some important indicators-self-control pre-conditions. In relation to that, we put a special accent on: adoption of new rules of values and behaviour; setting clear demands by a teacher; consistent setting of borders of the children's behaviour, verbalisation of some activities, establishing clear and specific rules, redirection and support instead of punishment and awards.. The key question we tended to get an answer for during this research is the way in which the teachers stimulate obedience that does not have a common meaning of subjugation, but appears as a result of willingness that is self-controlled. In relation to that, we put a special accent on: adoption of self-controlled willingness and which, as such, represents a special quality for personal and social progress.
\end{abstract}

Key words: self-control, discipline, obedience, institutional context.

\section{Introduction}

It is not possible to talk about self-control independently from other aspects or factors directly or indirectly determining the course of early education. First of all, we mean stimulant environment and qualitative support of teacher (an adult). Actually, it is holistic approach emphasizing complete context of the institution for early education. Therefore, we will tend to explain in the first part of the paper the key postulates and their specific influence on our subject of interest. We will also try to perceive stimulant or even limiting indicators of self-control and self-discipline through interactions with teacher and peers. Foundation for many of those influences we found in theories of Erickson, Vigotsky, Bronfenbrener, as well as pedagogical aspects of Maria Montessori.

\section{Self-control in context of contemporary institution for early education}


Contemporary understandings of early education emphasize all benefits and importance of this period for learning and development of child. Thereby it is truly believed in developing potentials and abilities, and active participation is sure. Socio-constructive theory establishes such aspects. Child in early age is conversant to other children and adults. Environment in which children are educated offers or limits their development. "Just in that co-relation with their physical (ecological) and social environment, child reveals meanings, examines and checks their hypotheses, develops new mental structures, learns about the world they are surrounded by, and gradually accepts new values, builds attitudes and way of lives in the culture they belong to". (Petrović-Sočo, 2009, page 11). Anyway, it seems it is more appropriate to talk about context of the institution, than the surroundings. When we say context we usually think of physical dimension, and we probably see it as a frame or we identify it with the surroundings. However, as we had previously emphasized different kinds of interactions in the surroundings, that way there is no context existing isolated from different subjects functioning in it. It is a dynamical category which besides physical also includes social, cultural, and even timely aspect. Context of the institution for early education could be defined as "a living organism, as a complex, dynamical content, as an interactive network of social, cultural and ecological (physical) and timely relations that a child is in constant interaction with ". (PetrovićSočo, 2007, page 36, according to: Stoll i Fink, 2000, Capra, 1986 i Snge, 2003).

When we say discipline, then we usually think about rigidness, obedience, etc. Somewise, we can relate it with negative opinion on discipline, in which external authority prevails. Control is done arbitrarily and punishment isn't rarely used. (Kamenov, page 227). Taking into account different educational styles, as opponent to this one, teacher can go to other extremes and be too permissive. Although we could say, to inertia, that the solution could be found by converging these two strategies, actually it is not like that. The problem is much more complex and the base should be searched in adequate social frame. It means: understanding of child's needs, reliable value and stable figure of an adult-teacher. (Kamenov, 2008, page 227).

In the process of self-control development the most important role undoubtedly belongs to adults-teachers and parents. They should be experts in watching and listening to children. However, it is not spontaneous, intuitive recognition of children's needs and later again about spontaneous acting by teachers. On the contrary, initiative, independence, activity and overall development in different domains require very conscious, reflexive acting of teachers. Reflexive practicians have their own teaching philosophy, they always reconsider themselves, and earlier experiences are tested in new situations and contexts. Teacher is very often in situation to act directly, to apply knowledge in action. We will agree that such a practician does not suit their traditional attitudes, so reflexion necessarily means mental level.

Behaviour of children is the mirror of a teacher or what he does. To stimulate discipline and self-control, they have to be disciplined themselves. First of all, teachers must know to take "break" between impulsive "feeling" and "taking action". The technique that we, that way, demonstrate to children is so called time-out (the time enabling us to "remote" from the problem and regain emotional stability. (Nelsen, et al., 1996, page 50).

Adults-parents and teachers have a huge role in constructive direction of impulses. Through interaction and communication with adults, children learn how to control impulses, overcome troubles, and postpone pleasure (Seefeldt, Barbour, 1998, according to: Calkins, 1994, 4). That could be realised in various situations, such as mediating in conflicts when in such purpose a child "is stirred to recognise conflict, share opinions, come to agreement on solution, and to estimate and apply new behaviour" (Jurčević-Lozančić, 2011, page161).

Role of teacher is supporting for adoption of basic rules of behaviour and values, whereby possibilities, wishes and overall personality of a child must be respected. Such support is not the same as demonstration of certain rules that would be mechanically practised and permanently adopted later through simple imitation.

It seems that our practice is just "burdened " with traditional control over child. There is often imposed strict organisation of sleeping and eating schedule which implicitly express the need for control. However, help of an adult does not mean permanent dependence of a child on an adult, nor it means subdual to authority, but helping a child to get rid of that dependence gradually. Namely, here we can see contradiction: child is traditionally seen as helpless, dependent, and at the same time should be adapted (to be flexible) when it comes to life rhythm in the institution. "On one side children are not trusted so they are not allowed to do what they can already do by themselves at that age (for example: washing hands, clearing our after meal, recognising their bottle, etc.), and on the other side they are at the same time expected to do what they cannot do (delaying need for food, sleeping, drinking, playing)." (Petrović-Sočo, 2009, page 33).

Assumption of adopting a rule is that a child understands its meaning. Therefore, the explanation should be given, which means giving reasons why is something acceptable or vice versa. "Facts show that giving reasons to children is the most important individual factor influencing later development of self-controlled behaviour." (Walsh, 2001, page 60). 
Significant support to self-control development and overcoming of impulsiveness is enabled by setting clear requests by a teacher. Instructions are often insufficiently specified, so it seems that the child has an alternative of choice. For example, a teacher says: "Ana, can we sit down?" while she offers an alternative. Such request can be ambiguously interpreted, and it is certainly confusing, especially if we have children from different cultural milieus in the kindergarten. (v. Katz, McClellan, page 67-68). This certainly should not be identified with "strict educational regime" , but we emphasize necessary explicitly in messages sent by teacher.

Role of an adult also reflects in consistent setting of boundaries of children's behaviour. "Since the childhood, children are motivated for meeting the environment and discovering domains of their own acting" (Phillips, 1999, page 24). Besides consistency in relation to children, an adult should treat the other adults in the kindergarten according to the same principle (which is not the only one).

Behavioural concept ensures children's development in dependence on external corroboration. In that sense, prizes are usually used as stimulation means. However, "if children are only awarded, there is little chance for them to develop their own control and self-discipline." (Seefeldt, Barbour, 1998, page 262). Support and redirecting are far more efficient means. That is the way to build up the forms of behaviour that the child is motivated for. With techniques of support and encouragement we actually valuate made effort, no matter what the end is like. Indirectly, we also stimulate different patterns of behaviour. For example, we give careful and specified support: " I've noticed that you had stood up and moved a chair to the other place when Edi stubbed you this morning. I appreciate your self-control and tendency to solve this situation in such a peaceful way". (Nelsen, et al., 1996, page 6). Real encouragement actually means gentle, but specific enough, i.e. concrete feedback.

On the other side, instead of punishment, it should be talked about redirection of activities. Child is said what should not be done and is given information on how to act. When we punish children, we actually don't teach them how to do something properly, on the contrary-they learn how to avoid punishment in the future. Much more efficient than punishment is explanation of a situation to a child. "Surveys have shown that the most efficient way of discipline "facing" with inappropriate behaviour is the "non-punishing" one (Katz, McClellan, 1997, page 71). Of course, it means giving simple and very convincing reasons for concrete "discipline actions" by a teacher.

The teacher applying logical consequences actually expresses reality of social order. That is the way to represent a group of rules that have to be adopted as an assumption of successful functioning within a group. (Seefeldet, Barbour, 1998, page 271, according to: Dreikurs, Greenwalk \& Peper, 1982). This system sets a clear connection between a concrete procedure and consequence, and therefore punishment is not necessary. System of logical consequences eliminates anger, expresses an open attitude, support for self-control development. Besides, it expresses mutual respect between children and adults, which is a condition for development of autonomy and acceptance of acceptable behaviour.

Interactions among children inevitably get to social cognitive conflict. Knowledge is acquired and communication is reached on that base. "Children look at other children, they imitate them and later it becomes a part of their own behaviour". (Seefeldet, Barbour, 1998, p. 261). In the case of peer interaction, there could be an adoption of certain rules, and later a self-regulation. "Child moves from external regulation done by advanced peer towards its internalisation i.e. self-regulation of activities (The same, page 91 ). Therefore, it would be probably desirable to make groups consisted of children of different age.

Social interaction improves zone of proximal development. Vigotsky defined the ZPD as a "distance between the level of real development determined by independent solving of problem and the level of potential development determined through solving of problem according to directions of an adult or in cooperation with more capable peers" (Berk, Winsler, 1997, page 24, according to: Vigotski, 1978, page 86). It is important that children have interaction with somebody (participants can be adult-child or child-adult) in order to reach the goal by joined forces.

In order to get a real cooperation and to communicate successfully during the common activity, it is very important that participants work on reaching the same goal. Important quality of good "ferries" (metaphor that appeared in literature to describe effective interactions of teaching/ learning within ZPD) is subjectivity. That is the concept referring to the process in which two participants, who start the task with different understanding come to the common understanding. (Berk, Winsler, 1997, page 27, according to: Newson and Newson, 1975). Inter-subjectivity provides common base for communication while one of the partners is adjusting to perspective of the other. So, it is essential that participants in social interaction negotiate and look for a compromise in accordance to ZPD of the child.

Of of goals of the so called "ferry" is stimulating self-regulation. In that purpose, an adult should allow a child to regulate common activities whenever it's possible. That means that as soon as a child could work independently, an adult should 
revise control and power. "As soon as the common goal is reached, active withdrawal of an adult as a response to take over by a child is essential for self-regulation development". (Berk, Winsler, 1997, page 30). Degree of explicitness of the request made by an adult during interaction significantly determines child's self-regulation. "When adults constantly influence behaviour of a child through explicit commands and immediately give answers to current problems ("Put it here". "That's the green one"), learning and self-regulation are reduced. As a contrast, when teachers and parents regulate behaviour of children by asking questions which allows children to participate in revealing answers, learning and selfregulation are maximal". (Berk, Winsler, 1997, page 30, according to: Neal, Williams 1990; Roberts i Barns 1992; Gonzales 1994).

According to Maria Montessori assumption of self-control is a developed will. If developed properly, will is a stimulating strength, foundation for progress. Further on, she emphasizes reciprocity of will and obedience. Being obedient means practiced will. It cannot be formed outside. In order to get a child adopt a certain order, to develop self-control, it is necessary to gain attention of a child, come to those hidden potentials and motives that are "unconscious". In the second conscious period, there is expressed activity of will, which can be guided later. It is similar with obedience. "In the first period, the period of internal disorder, child is not obedient, and it seems like being psychically deaf, insensitive to commands; in the second time a child is willing to be obedient, acting like a person receiving a command and willing to respond it, but cannot do it or not always successfully, which means that the child is not ready yet and does not feel joy in being obedient; in the third period the child is ready to respond, with thrill; and with the child, with improvement in practicing, there is a joy for being able to be obedient" (Montessori, 2001, page 238). Obedience coming out from practicing will enables the own control. That is not blind obedience, that is responding to request of the one who provides them the "right to require " with their authority and abilities, as well as responsibility.

Self-control of children also depends on overall climate which, among other things, should offer: honest, not declarative respect of children and their rights; timely recognition and satisfaction of children's needs; adequate model of teacher's behaviour capable to reconsider their actions. (Petrović-Sočo, 2007, page 88). Environment should be flexible in order to be modified in accordance to children's needs. It is important to provide qualitative conditions for satisfaction of primary children's needs (for food, sleep, etc). Satisfaction of primary needs with children in early age enables gaining of safety. If it is not reached, it is difficult to influence development in any domain.

Development of internal control is particularly contributed by a well planned and consistently achieved regime of life, but which is elastic enough to be adjusted to children's needs and potentials (Kamenov, 2008, page 232). According to that, schedule of activities should be individualised in as high degree as possible, especially with children in early age. It is often vice versa in our practice, teacher is impatient, wants to feed the child as soon as possible, communicates roughly, he is ready to punish the child. (Manojlović, Mladenović, 2001, page 85). Instead of present overriding regime of the day, there should be a frame, but not the rules carried out with no exception.

Self-control is the process started in the early childhood. In nature, it is long-term and complex. Kopp (1982) emphasizes that the willing control (as response to mother's request) can be noticed in the last quarter of the age one (Joffe, 1979; Stayton, Hogan \& Ainsworth, 1971). Such attitude would be surprising for many theorists, first of all because there were not many researches done for the age under three. Willing control is developed during the whole pre-school period.

Developed self-control is a precondition of developing will, ability of concentration and independence of a child. The child is ready for cooperation for which was stimulated by internal motives. Child is able to accept request, to listen to it, but not only for "pure" obedience. Confirmation for that is asking for explanations, reasons, different options of solutions for some problem. More attention, persistence enable successful realisation of begun activities. Its consequence is development of independence, "supported" by the teacher. The major importance of self-control is probably reflected in that.

\section{Method of research}

Taking into account the nature of chosen problem, it was necessary to provide a holistic access to its examination. Thus we tried to establish the nature of different interactions in kindergarten context. Besides systematic long-term examination (lasting for two months), we have also done group interviewing. The goal was to get the whole picture on which factors influence self-control education, and how much does the whole climate contribute or limit its development. Taking into account all above mentioned, we have chosen the qualitative type research. In that sense, for understanding and interpreting given data, it was extremely important to include examinees-teachers, who helped our evaluations through their 
own experience (implicit pedagogy). Finally, we mention that the research, done in the scope of a educational unit in Niksic, was not focused on size and representativeness of the sample, but on deeper analysis and understanding of chosen problem.

\section{Results of researches and discussions}

The first impression we got during our visit to the kindergarten was that it was a very comfortable place for learning and stay for children. Groups were divided in: day nursery, kindergarten for younger and older children. Taking into account that we wanted to determine which way teachers stimulate development of self-control in early age, we have chosen the long-term watching of the younger group of children.

The object was structured in the way that it was made of two separate classrooms for each of the above mentioned groups, with separate dining room. As we were informed by teachers, they were privileged in that sense, as in other units food is served in the classrooms. Door of the classrooms-bedrooms are almost always closed. Cloakroom is placed in the hall. After they arrive to the kindergarten with help of their parents, the children put on little slippers and put off their jackets. Neither teachers nor children wear uniforms. Teachers meet the children kindly and smiling.

In the study where the younger group of children stay there is a special desk for a teacher placed in the corner of the room; four tables placed according to interests, bookshelves with toys and didactical material, bookcases. On the walls there are works of children on a particular subject in a particular time period (domestic animals, pets, heralds of spring). Colours are vivid and warm, including those on carpet and curtains.

After usual roll-call, regime of the day is continued by going to breakfast, after which comes the work on specific activities (firstly on the level of the whole group, and later according to interest centres), finishing usually with some musical or activities for relaxation. After that comes lunch, going to sleep. How much the regime of the day is schematic, flexible, and how much it is a stimulant frame for development of self-control we conclude on the base of expressed opinions of teachers, as well as our direct insight.

According to statements of the teachers, there is no exclusive insisting on routine order, but there is possible flexibility with obligatory respect of behaviour rules. However, to the question is it possible to individualise schedule of activities (for example Do all children have to go to sleep at the same time), we got a reply: "we cannot do that, that is not possible; they were learned to be quiet, although they don't sleep; it could be done if there is a special room for sleeping"..." "there are children who do not need day sleep, that is the reason why private kindergartens are favoured ". Other teachers would agree that children often refuse to go to the kindergarten because of day sleep. They mentioned lack of space as the major problem. "We are aware that it would be good if we had a room where children who don't sleep could stay, but the problem is exclusively technical". One of the examinees said that she had seen it in some kindergartens in other towns, so changes in their kindergarten should be surely directed that way.

When it comes to time organisation, we have also got an impression that it is not flexible enough. Washing hands and consuming food is done on frontal level; there is queue and it is usually crowded. As well as for sleep regime, we got an explanation that no exceptions are made in that case, so there are rules and order, and that getting used to the same is important. We remind to contradictory we have expressed in the scope of theory organisation and that is that the children are asked to do what they are not ready for, and to adjust to current needs disregarding certain regime. Only treating children reflects perception of them as dependent on adults, and they are at the same time asked to adjust. Our attention was especially attracted by a child that constantly "came out" from "a train" coming with breakfast. A teacher commented it in a way: "He has been here for months and hasn "t learnt to get into line yet".

It also seems contradictory that teachers consider satisfaction of primary needs of a child as extremely important, but on the other side we haven 't noticed flexibility (individualisation) in their satisfaction. We have already mentioned satisfying of the need to sleep, and the similar is with food. All children go to breakfast and lunch at the same time; sit and wait for their portion. Possibilities for research are limited, taking into account that they are not allowed to pour tea or milk by themselves, and very often the food is broken into pieces. We emphasize example of a boy who was taking a cup and putting it on his ear to drink his tea. He would do it for several times, and his teacher would say to put it down. Only when the child sitting opposite his did the same with his cup, the teacher realised they were playing phones. There are not rare cases that the teacher feeds slower children.

We did not get the impression that study room ambient is stimulant for research. Materials and toys are available for children, but the teacher mostly has planned course of activities. Instead of free choice of activities, they are mostly selected 
by the teacher with explanation that "the weaker ones cannot glue paper balls in drawn figure, but they can paint it". Of course, question of freedom is made here as well. However, to the question "How does the discipline start, what is the precondition for discipline, we ve got a reply "through likeability, attractiveness, we adjust activity to the age, focus attention, then we make a request". Focus on work was apostrophe. There is an obvious gap between planned in advance set of activities and tasks on one side and focused attention and interest on the other side.

We have already emphasized that the environment in the watched kindergarten was not stimulant for research. That is contributed by prevailing isolating culture of the institution as well as absence of attractive material. Namely, groups are separated, and architectural solutions do not give possibility for any flexibility of space. Even the doors of studies, besides the fact that they are always closed, are wooden, and windows are high on the top, so we cannot speak about transparency in that part. In the studies, first of all, there is no enough space for free moving. In conversation with the teachers, we were given an explanation that only the study for the older group is bigger and that it is a unique case, not only in their kindergarten but wider, in the whole town. Besides the existing toys, picture books and prepared didactic material that we have noticed on arrival, there were no significant changes during the stay in the institution. The exception is a couple of toys which, as the teacher said, they had got from the older group. Natural materials were not exposed in the study, but the teacher would take them for in advanced prepared activities and selected them as needed. She would usually keep them out of children's reach. As it comes to work according to interest centres, we emphasize that we have discovered through conversation that the children prefer construction centre, but not the rest of "directed activities". We will allow ourselves the statement that the centre was best equipped, which could be an indicator why the other centres are not stimulant. Anyway, there is certainly an open question remained, why this exact centre is favoured most.

In addition to flexible organisation, i.e. individualisation of activities there are statements that the program is flexible, that is is featured by work according to interest centres and thematic planning. "Some topic started today could be finished the following day, the following week". The goal for all of that is focusing attention, stimulating interest at children. However, the impression we got during our visit to the kindergarten refers to already prepared topics and activities coming out from it. Especially noticeable was the statement of a teacher: "I prepare everything for the next week". We appreciate an effort made in preparation of different materials for work, but taking into account current interest of children seems problematic. Such access was regularly repeated at other teachers as well. Namely, they emphasize the benefits of long-term occupation with a certain topic, but it seems that they don1t leave space for needs and interests that can interrupt already planned course of their activities. To the question do you act reflexively and which types of reflection to you often use, we got a reply "we think, especially if we had an unusual situation, that is necessary, that's our job like". It seems that implicit pedagogies of a teacher do not differ much in that sense. Besides, we think that reflection as a kind of learning is not quite present in their work yet. We got confirmation for that through other indicators as well, and some of them will be mentioned in this paper. With the above mentioned we wanted to at least generally expose some elements referring to spaciousmaterial and time dimension of context of the institution we visited. In the further exposing, we will focus on some of concrete indicators regarding self-control.

We consider extremely positive the fact that the teachers use their personal example to emphasize importance of selfdiscipline and self-control development. "We have to be the example so they could follow us. You are a role model for everything (of behaviour, creating hygiene habits, indicating). We don't miss the opportunity for learning from own mistakes, although it is hard in large groups. We have to show what is right-how to do hygiene habits, sit at the table, and behave according to Bonton- "here you are, please...". We also appreciate that the teachers recognise and use technique of "time-out". As they emphasize "you have to control yourself, and in a nice way, smiling you can say anything".

Discipline is, first of all, recognised as knowing and following the set of rules. "Order, respect, mutual respect, rules in behaviour; order is followed since the day the children start coming to the kindergarten, we insist on mutual respect; we remind children on rules and order, especially in the first month of their arrival". They emphasize how important it is that children want to cooperate in that process, i.e. if it is necessary to respect needs, wishes of the children and create a stimulant frame on that base. Our attention was attracted by the statement: " Rules of behaviour are well known, they know how to behave in the study, in the garden; there is the furniture that is dangerous. We especially underlined the dangerous furniture, because this statement has stirred us to think whether it meant stimulating of self-protection or watching of a child as independent. We think that it is early for us to comment what is the background of this statement, which does not mean it can be indicative.

Delaying of impulse, pleasure as a pre-condition of self-control development, as the teachers emphasize, could be realised by verbalising, talk. We have often witnessed, during our visit to the kindergarten, the interpretation and explanation of different situations, stimulant for self-regulation. We mention some of them: "Is that nice what Gojko did, 
you don't touch temperas with hands, paint is infectious, isn't it? Lazo, get up from the floor so we don't step on the paint... We cannot discover who it is, our game will fail...". Besides, the teachers emphasized necessary explicitly in making requests to the children. They emphasized in the conversation "we have to be specific, if we don't act clearly and concretely we cannot expect from the children to respect our requests". Concreteness is necessary to get the reply and change of behaviour". During survey we have also got the impression on explicit of request, for example "listen carefully, take one strip each, do not crimple, then put the glue; take one popcorn and glue; now sit at the tables; who the teacher call, he calls his friend; put back the crayons, we take only one...". On the other side, we did not notice so much that the teachers use positive terms in establishing rules of behaviour. In conversation with them, we got an explanation why it is so. As they say, the children easily understand the statements such as "is it nice, don "t hit him", than "tell him it is your turn". It is certain that they are prone to making statements, explanations for certain situations and requests. Anyway, formulating of positive terms, as to the rule, is lacking. As they say, their formulations are not negative, nor extremely positive. They describe them as specified messages, with necessary individual access, and obligatory pleasant tone. "We don 't use negative connotations, we tend to make child understand the request, saying it in a pleasant way". On the base of the previously mentioned, it is certain that teachers explain why something is acceptable or unacceptable". As they emphasize, that is especially important, because the children often don't understand why is something problematic, why they get or do something. "Even if we didn't do that", they say, "the children ask for explanation".

Consistent setting of limits of the children's behaviour is especially important dimension. We did not doubt that they will be confirmed in the conversation, but we had to make a certain effort in watching the same, and on that foundation base conclusion. We could generally say (although we should take into account the time we spent in the kindergarten) that there is principle in setting the rules and then in following the same. We especially emphasize the statements of the teachers who said: "we are trying to be consistent. If we make a mistake once, they use it. They can remember, they can learn, but also to use that if you are not consistent". Such statements matched our estimations as well, as the cases of inconsistency that we have noticed, were mostly sporadic.

Further on, we paid attention to strategies of learning social norms, as a pre-condition of self-controlled behaviour. We asked the teachers what, of the given, they use the most: being a role model, replacement and redirection, setting of rules of behaviour or implementation of certain consequences (Walsh, 2001, str. 58). During the conversation, we have confirmed the importance of role model, the personal one, as well as looking at positive examples of children. As they say, those are the children being awarded for something, and therefore can be a stimulant role model for other children. In the further course of conversation we tended to identify what do the teachers do when a child tries to follow a rule?

In the most cases we got a reply that such behaviour is awarded. In the further course of conversation we saw that that is the common type of award and realised that those are not just awards, but they also use praise. There were the excellent comments as well, such as this one: "they are the happiest when we give them sweets". Further reconsidering justifiability of awards and praises, we realised that the teachers encourage the children (we saw it during the survey), and they use the praises in a moderate way, so they do not favour children and negatively influence confidence. Here we also had some unexpected statements that they got instructions during the specialisation that every procedure or made effort of the child should be praised, which is unjustifiable for the above mentioned reasons, in their opinion. We found helpful the words of encouragement, which we could hear very often: " You do it really well", "Excellent, just go on with your work", "How come you cannot do it, we can all do it"... There were the negatively connoted, such as: "Look at Gojko, he will never work with temperas again...". Anyway, such statements were exceptional.

In the further course of conversation we actualised the question of sanctioning unacceptable behaviour. The teachers unanimously said that they do not apply punishing. During the survey we noticed that the teachers used to say "you will be punished " when communicating with children. Emphasizing the system of logical consequences, as positive and above all helpful solution, we realised that it is still mot a part of their repertoire of behaviour. As the examinees emphasized, it is not "really practical" to ask from a child to clean the spilled milk, because he gets stained". It happens sporadically: "only when they throw bread on each others, they pick up the crumbs".

In the theoretical part of the paper we have emphasized the importance of social interactions in relation teacher-child and mutual interactions of children. It is searching of compromise suiting the ZPD of a child. In accordance with that, we asked the teachers if they are prone to reduce help and control when they notice that the child can do independently. Replies we got are quite confusing: "Yes, persistence is important", "I don't allow them to give up, although they are not good at it, you saw when they were making the balls", " In dependence on situation and activity", " You must have control and mustn "t leave the child alone". In order to complete and in a way clear our the given replies, we asked them if they could immediately respond to current problems. Unlike the previous question, here we got explicit reply that you must have 
patience, make sub-questions, instruct work, getting to reply and check the understanding. They have also explained additionally that -it all depends what is the purpose of the task; in some situations it is completely irrelevant whether we will immediately say the colour, if the point is something else, but if the purpose is to recognise a colour, they will certainly not get a ready reply".

In order to approach any generalisation in this part, we have to get back to the beginning analysis of context and prevailing interactions in it. Namely, planned activities the teachers start to realise on frontal level (through storytelling, poem, etc), after which comes again planned set of activities done according to interest centres. In that spirit, communication on the level of the centre itself is continued, with prevailing frontal requests. There are occasionally some individual referring, such as: "Do you need my help?... Just don't pass the line", "I'm coming Aco, just after I help Dik", "You don't need help, you can do it by yourself". There is certainly will and tendency to realise a certain task through support and that they, according to the need, are reduced or redirected to the other children. Anyway, it seems problematic the whole way of acting, starting from spacious-material dimension of context, work in the centres, unattractive material... Teachers on theoretical level understand the essence of discipline, as they understand the importance of thematic planning and work in accordance to needs, abilities and interests of children. However, spirit of collective discipline (rules of behaviour and the same regime for all), absence of cooperation in the widest sense of word and planned activities are contradictory to previously mentioned theoretical postulates.

It is noticeable that the teachers already have the need to realise planned activities, disregarding possible variations in interests of children. That was contributed by the managing role of the teacher during realisation of the given activities. Besides that, they would often reduce chance for research in a way that, in our opinion, they did some activities instead of let the children do them (putting glue, prepared paints...). Besides all that, directive communication, placing giving instructions in the first plan, requests worth for all, contributed creating of climate more suitable for teaching than independent, spontaneous research.

Taking into account the range of this paper, we note that we won't be occupied with the question of peer interaction more studiously. Anyway, we will generally mention some of the indicators that are important for self-control and that give us a whole picture of overall context of the surveyed institution.

During the interviews, the teachers emphasized the importance of the mentioned interaction. According to them, structure of the group is extremely important. According to their statements, the group we watched is much worse than those in previous years. Then they explained to us that it corresponded with family structures, styles of parenthood, etc. They think that the problems are negative role models that the children look up to.

"Children look up to their peers, they rather adopt negative models, which we certainly try to prevent... "if a friend painted something precisely is less relevant than if someone upturned a chair"..." if one or two children adopt it, they will explain to the third child".

On the base of survey we got the impression that, in a few times, elaborated style of work does not leave space for truly cooperation and on that foundation based learning. Even if an activity was imagined for a group, there is no real interaction between children. When we apostrophe the above mentioned in conversation with the teachers, they told us that taking into account the age, it is illusory to expect that the child will manage in a group, so it is justifiable to use pair work. Again, we have to get back to common way of work, which is not adjusted to individual interests, nor it has characteristics of problematic, provoked learning. In that sense, we could mention again the lack of attractive material, as well as inflexible organisation according to interest centres. As there is mostly individual work even in the group, the children are not able to develop the feeling of closeness and acceptance. Such "group" work does not offer chance for truly exchanging of ideas, as the teacher does not leave the space for spontaneous dialogue among them, nor prepare activities that could be focused on accomplishment of the common goal, which gives the cooperation the real sense. We have to keep shortly on the statement that "if one or two children adopt it, they will explain to the third child". Here, as well as in other places, we get indicators offering optimism.

Disregarding the previously described context of the visited institution, we consider that certain indicators, regarding discipline, are positive.

\section{Conclusion}

Theoretical, as well as empirical interpretation of our subject of study, we started with the story on context. In that sense, we especially emphasized the spacious-material and time dimension of context. 
Spacious-material dimension is featured by a quite dysfunctional space (isolated studies, insufficiency of material, inadequate architectural solutions etc.). Anyway, optimism is still reflected in bookshelves, cloakrooms available to children and bottles, warm colours...

Time dimension is recognised as "common regime of work", in the scope of which, disregarding individual needs and tempo, hygiene habits are practiced, they have breakfast, lunch, go to sleep..." stay in the kindergarten is a pattern, it is determined when they come, when they have breakfast, sleep", the teachers say.

Environment, i.e. the whole climate has the seal of teaching. Namely, the prevailing frontal start of activities at the beginning of the day, over planned activities according to interest centres, to insufficiently and stimulant material.

Above mentioned refer to presence of isolating culture, as well as to insufficient awareness (reflection) of the own practice. This, all the more, if we take into account the statements of the teachers on necessary individualisation, thematic study and stimulation of children's interests, and which are opposite to their practical work.

Starting from such an implicit pedagogy of the teacher, we reconsidered the frame of discipline and in the scope of them chance of self-control development. That way we concluded that it is insisted on:

Following the rules of behaviour,

Explicit requests,

Explanations,

Consistent in establishing of limits of the children's behaviour...

The above mentioned should be added motivation with praises and encouragements, but also insufficient implementation of logical consequences in purpose of sanctioning unacceptable behaviour and stimulation of the acceptable. Although here mentioned statements stimulate self-regulation, there is the question in which measure it is possible in the previously described context, and what is their reach. According to what was seen, it seems that it is more about discipline in collective spirit than behaviour motivated by self-control.

We have especially emphasized the nature of interaction between the teacher and child in the prism of context of the visited institution. Teacher usually invites all children to take part in activities, disregarding their interests. Therefore they all have the same requests in front of them, and they are all given general instructions. That certainly emphasizes traditional role of the teacher, and on damage of the watching, listening, planning one. That way, the already well-known teaching of Vigotsky on the zone of proximal development is put in the second plan. It is not difficult to conclude that on described foundation based communication is mostly linear. With no pretension to widely elaborate interaction between children, we have generally mentioned it, as it is extremely important in the self-regulation process. The previously indicated interaction and communication from relation teacher-child has been undoubtedly transferred to mutual relations of the children. Direction of all to listen to the story, to work mostly on their own tasks in groups, to be motivated more to exchange in their own, and especially with other groups, the consequence was mutual mistrust, non-acceptance, even conflicts. It is not hard to conclude that in such conditions, chances for cooperative learning are limited.

Finally, we state how much the described context is stimulant for teaching self-control. Maybe it is the best in that sense to pay attention to the prefix only. Is the child in the surveyed conditioned treated as independent, autonomous, i.e. dependent and helpless? It is clear that we cannot conclude on self-control non-contextually, and if we 0 it, we find reply in the other part of the mentioned question. Therefore, the attention is paid to discipline, but the circumstances in which teachers act, as well as their implicit pedagogies, should be quite modified in order to develop self-control at children at those bases.

\section{References:}

Berk, L., Winsler, A. (1997). Scaffolding Children's Learning: Vygotsky and Early Childhood Education. Washington: NAEYC.

Bronfenbrener, J. (1997). Ekologija ljudskog razvoja. Beograd: Zavod za udžbenike i nastavna sredstva.

Erikson, E. (2008). Identitet i životni ciklus. Beograd: Zavod za udžbenike i nastavna sredstva. 
Jurčević-Lozančić, A. (2011). Socijalne kompetencije i rani odgoj. Nove paradigme ranog odgoja, 153-174. Zagreb: Filozofski fakultet Sveučilišta u Zagrebu.

Kamenov, E. (2008). Vaspitanje predškolske djece. Beograd: Zavod za udžbenike.

Katz, L., McClellan, D. (1997). Fostering Children's Social Competences: The Teacher's Role. Washington: NAEYC.

Manojlović, A., Mladenović, U. (2001). Psihologija predškolskog djeteta. Beograd: Centar za primjenjenu psihologiju.

Milić, S. (2008). Savremeni obrazovni sistemi. Podgorica: Univerzitet Crne Gore.

Montesori, M. (2001). Otkriće deteta. Beograd: CRS.

Montesori, M. (2006). Upijajući um. Beograd: DN Centar.

Nelsen, J., et. al., (1996). Positive discipline: a teacher's A-Z guide. USA: Prima publishing.

Nubrown, C. (2006). Key concepts in Early Childhood Education \& Care. London: SAGE Publications.

Petrović-Sočo, B. (2007). Kontekst ustanove za rani odgoj i obrazovanje - holistički pristup, Zagreb: Mali profesor.

Petrović-Sočo, B. (2009). Mijenjanje konteksta i odgojne prakse dječijh vrtića - akcijsko istraživanje s elementima etnografskog pristupa. Zagreb: Mali profesor.

Philipps, S. (1999). Montessori priprema za život. Jastrebarsko: Naklada Slap.

Popović, T. (ur.), (1997). Problemi vašeg djeteta. Beograd: Zavod za udžbenike i nastavna sredstva.

Seefeldt, C., Barbour, N. (1998). Early Childhood Education - An Introduction. New Jersey: Prentice-Hall, Inc.

Šagud, M. (2006). Odgajatelj kao refleksivni praktičar. Petrinja: Visoka učiteljska škola.

Vajkof, Dž., Anel, B. (1996). Vaspitanje bez batina i suza. Podgorica: Dječiji savez Crne Gore.

Vaughn, B., Kopp, C., Krakow, J. (1984). The Emergence and Consolidation of Self- Control from Eighteen to Thirty Monts of Age: Normative trends and Individual Differences, Child Development, vol. 55, No.3, pp.990-1004., dostupno na: http://www.jastor.org/stable/1130151, 06.02.2014., 17:24;

Walsh, B. Kate. (2001). Kreiranje vaspitno-obrazovnog procesa u kojem dijete ima centralnu ulogu. Podgorica: Pedagoški centar Crne Gore. 